\title{
Online farmazia-arreta onkologiaren arloan: eredu pilotu berriak garatzen
}

\section{Online pharmaceutical care in oncology setting: developping new pilot models}

\author{
Mikel Urretabizkaia Anton ${ }^{1}$, Pilar Bachiller Cacho ${ }^{1}$, Josune Garcia de Andoin Barandiaran ${ }^{1}$, \\ Koro Andueza Granados ${ }^{1}$, Laura Basterretxea Badiola ${ }^{2}$, Miren Ercilla Liceaga ${ }^{1}$, Maitane \\ Umerez Igartua ${ }^{1}$, Larraitz Leunda Ezimendi ${ }^{1}$, Aitziber Lizardi Mutuberria ${ }^{1}$, June Landa Alberdi ${ }^{1}$, \\ Garbiñe Lizeaga Cundin ${ }^{1}$. \\ ${ }^{1}$ Donostia Unibertsitate Ospitale, Ospitaleko Farmazia Zerbitzua \\ ${ }^{2}$ Donostia Unibertsitate Ospitalea, Onkologia Medikoa Zerbitzua
}

mikel.urretavizcayaanton@osakidetza.eus

\section{Laburpena}

Helburua: Online eskainitako farmazia-arretaren (FA) eredu pilotu bat deskribatzea eta haren bideragarritasuna eta erabilgarritasuna aztertzea.

Metodoa: Online eskainitako FA zerbitzuaren esplorazio-izaerako ikerketa prospektiboa eta deskribatzailea egin zen, 12 astez, minbiziaren aurkako aho bidezko agenteekin tratatutako giltzurrun-minbizi aurreratua zuten pazienteetan. FA zerbitzua honetan oinarritzen zen: 1) medikazioari eta ondorio kaltegarriei buruzko informazioa ematea; 2) ondorio kaltegarrien galdetegiak eta pisuaren eta tentsio arterialaren jarraipena egitea; eta 3) pazientearen eta farmazialariaren arteko zuzeneko komunikazio-kanal bat ezartzea. Dena online, Osasun Karpetaren bitartez. Neurtutako aldagaiak FA programaren atxikidura, ezarritako komunikazio-kanalaren erabilera eta pazienteen gogobetetzea izan ziren.

Emaitzak: 24 pazienteri egin zitzaien elkarrizketa eta horietatik lauk (\% 16,7k) hartu zuten parte ikerketan. Parte-hartze urriaren arrazoi nagusiak: a) Internet ez erabiltzea (elkarrizketatuen \% 37,5), eta b) Osasun Karpetara sartzeko pasahitzak ez izapidetzea (elkarrizketatuen \% 41,7). Ikerketan parte hartu zuten pazienteen atxikidura ertaina, handia eta oso handia izan zen, eta denek erabili zuten komunikazio-kanal berria kontsultak egiteko. Oro har, guztiak gustura agertu ziren jasotako zerbitzuarekin.

Ondorioak: Osakidetzan eskuragarri dauzkagun baliabideekin, badirudi posible dela online FA garatzea. Pazienteak jasotako zerbitzuarekin pozik dagoela adierazteak haren erabilgarritasuna baieztatzen du. Muga nagusia parte-hartze urria izan zen, seguruenik pazienteen adin aurreratuak eta Osasun Karpetaren inguruko ezjakintasunak baldintzatuta. Etorkizuneko belaunaldien partehartze handiagoa aurreikusiz, online FAren eredu aitzindariak garatzen inbertitu beharko genuke.

Gako-hitzak: farmazia-arreta, telemedikuntza, sintomak maneiatzea, minbiziaren aurkako agenteak, kanpoko pazienteak, farmazialari klinikoak.

\section{Abstract}

Goal: Describing an online pharmaceutical care $(P C)$ pilot model and evaluating its feasibility and usefulness.

Method: A prospective descriptive and exploratory study of online PC was conducted, during 12 weeks, in patients with advanced renal cell carcinoma with oral antineoplastic agent treatment. PC included: 1) providing information about their medication and adverse reactions; 2) performing adverse reactions questionnaires and a weight and blood pressure follow-up and 3) establishing a direct 
patient-pharmacist communication channel. All was performed online through the "Health Folder". Measured variables were adherence to the PC program, the communication channel utilization and patients' satisfaction.

Results: 24 patients were interviewed and four (16.7\%) of them were included in the study. The low participation was due to: a) not being internet user (37.5\% of the interviewed); b) not applying for the personal "Health Folder" access code (41.7\% of the interviewed). Adherence to the PC program was medium, high or very high in all the study patients. All of them used the new communication channel to make their inquiries. In general, all were satisfied with the service received.

Conclusion: With the available resources we have in Osakidetza, the development of online PC seems feasible. Patients' satisfaction with the service received supports its usefulness. Low participation was the main limitation, and was probably conditioned by the patients' advanced age and lack of knowledge about "Health Folder". Foreseeing a greater participation of future generations, we should invest in developing pioneer online PC models.

Keywords: Pharmaceutical care, telemedicine, symptom assessment, antineoplastic agents, outpatients, clinical pharmacists

Bidalia: 2019ko azaroaren 8an

Onartua: 2020ko otsailaren $11 \mathrm{n}$

http://doi.org/10.26876/osagaiz.1.2020.279

\section{Sarrera eta helburuak}

Azken urteetan, diana terapeutiko eta tratamendu bideratu berrien aurkikuntzari esker, minbiziari aurre egiteko estrategiak aldatzen ari dira. Minbiziaren Aurkako Aho bidezko Agenteek (MAAA) garrantzia irabazi dute agertoki berri honetan, pazienteen autonomiaren eta erosotasunaren mesedetan. Erronka berriak azaltzen dira ordea: atxikidura falta, elkarrekintza eta toxikotasunarazoen ondorioz batik bat (1). Hala izanik, MAAAk arrisku handiko sendagai gisa sailkatuta daude Institute for Safe Medication Practices eta Joint Commission-en arabera (2).

Arrazoi horiek bitarteko, farmako horiek ospitaleetako Farmazia Zerbitzuetan banatzen dira, ospitaleko farmazialariaren aldetik zaintza eta gainbegiratze berezia behar baitute. Farmazialarien funtsezko zeregina da, beraz, pazienteen atxikidura sustatzea, elkarrekintzak aztertzea eta ekiditea, ondorio kaltegarriak maneiatzen laguntzea eta osasun-arazoen zaintzarako aholkuak ematea.

Diziplina anitzeko lantalde klinikoaren barruan, erizaintza eta farmaziako kolektiboek giltzarri gisa jokatzen dute pazienteen hezkuntzan, sendagaiekin lotutako arazoak kudeatzen lagunduz (3). Donostia Unibertsitate Ospitalean, terapian aldaketak dauden aldiro arreta pertsonalizatua jasotzen dute pazienteek, bai kontsultan, bai farmazia-zerbitzura medikazio bila datozenean ere.

Hezkuntza hori jaso arren, kimioterapiaren sintomatologia akutua ospitaletik kanpo dauden bitartean pairatzen dute pazienteek. Horrek zera dakar berekin: gerta litezkeen ondorio kaltegarriak saihesteko eta kontrolatzeko jarraibide orokorrak jasotzen dituztela, nahiz eta batzuetan ez diren egokitzen norberak garatzen dituen sintoma espezifikoetara (4). Beraz, sintomak prebenitzen edota arintzen saiatzeko, beren buruaren zaintzan parte hartzeko erantzukizuna (5) eta gainbegiratzerik gabe erabaki garrantzitsuak hartzeko ardura (6) dute.

Horrez gain, arazoak sortzen direnean, paziente batzuk osasun-profesionalekin harremanetan jartzeko beldur izaten dira (7). Garaiz jakinarazten ez diren sintomek okerragora jo dezakete eta konplikazio larriagoak ekar ditzakete. Hala nola ospitalera joan beharra edota kimioterapia jartzeko arazoak eragin ditzakete, osasun-emaitzak kaltetuz (8).

Hori dela-eta, pazienteei euren beharretara egokitutako laguntza egunerokoan eskaini beharko litzaieke. Informazioaren eta Komunikazioaren arloko Teknologia (IKT) berriek osasun-zerbitzu eredu 
berrien garapena ahalbidetzen dute, hala nola farmazia-arreta (FA) online eskaintzeko aukera. Abantaila nagusi gisa, pazienteek jakinarazitako sintomatologia denbora errealean detektatzen lagundu dezakete IKTek, esku-hartze azkar bat ahalbidetuz (9). Gainera, bide telematikoen bidez eskainitako FA zerbitzuek eragin positiboa erakutsi dute gaixotasunaren maneiu klinikoan, pazientearen autogestioan eta tratamenduaren atxikiduran (10).

Honengatik guztiagatik, FA telematikoa Farmazia Zerbitzuen parte den jarduera bezala ulertu beharko genuke, gizarteak eskatzen dituen aldaketetara egokituz (11). Osasun Karpetaren garapenarekin, IKTen integrazioaren aldeko apustu sendoa egin du Osakidetzak. Web aplikazio berri horrek historia mediko guztia pazienteen eskura jartzen du mugikorretik, tabletetik edo ordenagailutik kontsultatu ahal izateko. Honako aukerak eskaintzen ditu, besteak beste: txosten medikoak, preskripzioak eta hitzorduak ikusteko aukera, osasun-profesionalekin komunikatzekoa, Osakidetzatik kanpoko txosten medikoak norberaren historia medikoan txertatzekoa, autojarraipenprogrametan parte hartzekoa, etab. Hori guztia modu seguruan eta konfidentzialean, Datu Pertsonalak Babesteko Legea betez (12).

Osasun Karpetaren garapenak, beraz, ateak zabaldu ditu arreta-zerbitzu berriak online eskaini ahal izateko. Baliabide berri horren abantailak abiarazteko, giltzurrun-minbizi aurreratua duten pazienteekin hastea adostu da. Izan ere, paziente horiek hartzen dituzten MAAAek (sunitinib, pazopanib, axitinib, sorafenib, etab.) ondorio kaltegarrien profil bereizgarria dute. Besteak beste honakoak eragin ditzakete: tentsio arterialaren igoera (jarraipen estua komeni da), arazo gastrointestinalak (beherakoak, goragaleak, gorakoak...), oin-eskuetako eritrodisestesia, nekea, estomatitisa, apetitu-galera, gustuaren aldaketak, larruazaleko arazoak, etab.

Lan honen helburu nagusia, beraz, Osasun Karpetaren bitartez online FA eskaintzeko diseinatutako eredu pilotu baten garapena deskribatzea da, eta modelo hori bideragarria eta erabilgarria den ikustea MAAAekin tratatutako giltzurrun-minbizi aurreratua duten pazienteen sostengurako tresna gisa.

\section{Material eta metodoak}

Askatasunez parte hartzeko aukera eskaini zitzaien 2016ko abuztuan MAAAekin tratamenduan zeuden giltzurrun-minbizi aurreratua zuten paziente guztiei, ospitalean jasotako ohiko praktika klinikoan bestelako aldaketarik eragin gabe. Inklusio-irizpide hauek bete behar zituzten parte hartu ahal izateko: Interneten erabiltzaile izatea, Osasun Karpetan sartzeko klabeak edukitzea edo eskuratzea, hizkuntza-arazorik eza eta adostasun informatua sinatzea.

Ikerketaren helburuen eta ezaugarrien berri emateko hasierako elkarrizketa bana egin zen, informazio-orri bat banatuz. Parte-hartzearen inguruko erabakia bigarren elkarrizketa batean adierazi beharko zutela azaldu zitzaien, ordurako Osasun Karpetako pasahitzak eskuragarri edukita (baiezko kasuan). Pasahitzak euren osasun-zentroko bezeroen arreta-zerbitzuan izapidetzeko jarraibideak eman zitzaizkien, ahoz eta idatziz.

Bigarren elkarrizketan, ikerketan parte hartzeko erabakia hartu zuten pazienteek, inklusio-irizpideak beterik, adostasun informatua sinatu zuten. Osasun Karpeta erabiltzen erakutsi zitzaien.

Ikerketaren iraupena 12 astekoa izan zen paziente guztientzat, bakoitzaren inklusio-unetik hasita. Farmazia-zerbitzuan euren hileroko medikazioa jasotzerakoan, ohiko arreta jaso zuten farmazialarien aldetik, hau da, soilik terapian aldaketak zeudenean edota pazienteen kontsultei erantzuna emateko. FA aktiboa bide telematikotik burutu zen, Osasun Karpetaren bitartez honako ekintzak eginez:

- Atxikidura hobetzeko asmoz eta pazienteen erantzunkidetasuna pizteko, bakoitzari egokitutako kimioterapiaren inguruko informazio-estekak bidali zitzaizkien, ondorio kaltegarriak maneiatzen laguntzeko informazioarekin.

- Astean behin ondorio kaltegarrien inguruko galdetegiak bidali, eta tentsio arterialaren eta pisuaren jarraipenerako erregistro bat betetzeko eskatu zitzaien (ikusi 1. taula). Farmazialariek 
galdetegi horiek berrikusi eta pazientearekin edo medikuarekin kontaktuan jartzeko konpromisoa hartu zuten beharrezkoa izanez gero. Larritasuna aztertzeko, albo-ondorioak Common Terminology Criteria for Adverse Events (CTCAE) (13) eskalaren arabera sailkatu ziren.

- Albo-ondorioen eta elkarrekintzen inguruan farmazialariari online galdetzeko aukera erraztu zen, komunikabide telematiko berri bat ezarriz.

Komunikabide berriaren ezaugarriak honako hauek ziren: 1) edukia Osasun Karpetaren bitartez ikus zitekeen soilik, konfidentzialtasuna bermatuz; 2) pazienteak e-mail bat jasotzen zuen bere posta elektroniko pertsonalean, Osasun Karpetan farmazialariaren mezu bat jaso zuela ohartaraziz; 3) farmazialariaren erantzunak historia kliniko elektronikoan automatikoki erregistratzen ziren.

Neurtutako aldagaiei dagokienez, online gauzatutako FA eredu honen bideragarritasuna eta erabilgarritasuna aztertzeko, programarekiko pazienteek erakutsitako atxikidura-maila, ezarritako komunikazio-bide berriaren erabilpen-tasa eta pazienteen asebetetze-maila neurtu ziren:

$\checkmark$ Programarekiko zuten atxikidura-maila ikusteko, asteroko galdetegien betetze-tasa neurtu zen. Galdetegia erantzun zuten aste kopuruaren arabera, honako sailkapen hau egin zen:

$0-2$ aste: atxikidura oso txikia; $3-4$ aste: atxikidura txikia; $5-7$ aste: atxikidura ertaina; $8-9$ aste: atxikidura handia; $10-12$ aste: atxikidura oso handia.

$\checkmark \quad$ Ezarritako komunikazio-bide berriaren erabilpen-tasa neurtzeko, pazienteek egindako kontsultak zenbatu eta gaiaren arabera honako multzo hauetan sailkatu ziren: elkarrekintzak, ondorio kaltegarrien maneiua, administrazio-arazoak, kontraindikazioak, erabilera egokirako neurri bereziak eta beste batzuk.

$\checkmark$ Asebetetze-maila galdetegi baten bitartez neurtu zen (ikusi 1. irudia emaitzen atalean).

Donostia Ospitaleko Zuzendaritzaren, Onkologia Zerbitzuaren eta Gipuzkoako Ikerketa Klinikoetarako Batzorde Etikoaren oniritzia jaso zuen esplorazio-izaerako ikerketa deskribatzaile honek.

\title{
1. TAULA - ONDORIO KALTEGARRIEN INGURUKO ASTEROKO GALDETEGIA
}

Pisua: _ $\mathrm{Kg} \quad$ Tentsio arteriala:___ $\mathrm{mmHg}$

\author{
1. Sukarrik izan al duzu? \\ a. Ez. \\ b. Sukar pixka bat eduki dut, baina $38^{\circ} \mathrm{C}$-tara iritsi gabe. \\ c. Sukarra eduki dut, $38-39{ }^{\circ} \mathrm{C}$-taraino iritsi dena. \\ d. $39^{\circ} \mathrm{C}$-tik gorako sukarra eduki dut.
}

\section{Zure jateko ohiturak edota jateko gogoak aldatu dira?}

a. Ez dut apetiturik galdu.

b. Apetitu gutxiago daukat, baina betiko moduan jaten ari naiz.

c. Apetitu gutxiago daukat eta normalean baino gutxiago jaten ari naiz.

d. Nekez jaten dut ezer eta pisua galtzen ari naiz.

\section{antzematerakoan ezintasuna/aldaketak? \\ a. Ez dut ahoan inolako aldaketarik nabaritu. \\ b. Aldaketaren bat sumatu dut, baina orokorrean ondo jan dezaket. \\ c. Ahoko ondoezak nire dieta aldatzera behartu nau. \\ d. Pureak eta likidoak besterik ezin ditut hartu.}

3. Honakorik sentitu al duzu ahoan: mina, hantura, ultzerak, inurridura edota zaporeak

4. Egunean zenbat aldiz egin duzu botaka? 

a. Behin ere ez.
b. Behin edo bitan, egun batean edo bat baino gehiagotan.
c. Egunean 3-5 aldiz egin dut botaka, egun batean edo bat baino gehiagotan.
d. Egunean 6 aldiz edo gehiagotan egin dut botaka, behintzat egun batean.

5. Libratzeko maiztasunean aldaketarik nabaritu al duzu? Edota gorozkiak urtsuago?

a. Ez, beti bezala noa komunera.

b. Bai, nabaritu ditut, baina gehienez ere 4 gorozki urtsu egin ditut egunean.

c. Egunean 5 - 7 aldiz joan naiz komunera, egun batean edo bat baino gehiagotan.

d. Egunean 8 aldiz edo gehiagotan joan naiz komunera, egun batean edo bat baino gehiagotan.

6. Eskuetan edota oin-zoletan aldaketarik nabaritu al duzu (gorritasuna, hantura, inurridura...)?

a. Ez dut aldaketarik sumatu.

b. Aldaketak sumatu ditut, baina ez daukat minik.

c. Min ematen didate eta eguneroko zereginetan zailtasunak ditut (gidatzeko, etxeko lanak egiteko...).

d. Min ematen didate eta nire burua zaintzeko zailtasunak ditut (janzteko, mahai-tresnekin jateko...).

\section{Eguneroko jarduerak egiteko zailtasunik al duzu energia faltaren ondorioz?}

a. Ez, beti bezain ondo sentitzen naiz.

b. Nekatuta nago, baina atseden hartuz nekea arintzen zait.

c. Nekeak eguneroko zereginak egiteko mugatzen nau (janaria prestatu, erosketak egin...) eta atseden hartu arren, ez da arintzen.

d. Nekeak nire burua zaintzeko zailtasunak sortzen dizkit (janzteko, komunera joateko, dutxatzeko...) eta atseden hartu arren, ez da arintzen.

8. Halakorik sentitu al duzu: eztula, airerik ezaren sentsazioa, arnasteko zailtasunak edo mina sakonki arnasterako orduan?

a. Arnasterako orduan ez dut aldaketarik nabaritu.

b. Eztula badaukat, baina normaltasunez hartzen dut arnasa.

c. Arnasa hartzeko zailtasunak ditut eta airerik ezaren sentsazioa eguneroko zereginak egiteko orduan (oinez ibiltzeko, erosketak egiteko...).

d. Arnasa hartzeko zailtasunak izateaz gain, eztula, sukarra edota mina ditut sakonki arnasterako orduan.

9. Odoljarioen adierazgarri izan litekeen zeinurik izan al duzu?

a. Bat ere ez.

b. Erraztasun handiz sortzen diren ubeldura edo hematomak.

c. Sudurreko odoljarioak.

d. Eztularekin batera odolaren edo odoleztatutako mukien egozpena.

e. Odol-gorakoak, kafe-hondarren antzerakoak.

f. Odoleztatutako gorozkiak edo kolore beltzekoak.

10. Ondorengo sintoma hauetakoren bat sentitu al duzu? Bat baino gehiago aukeratu ditzakezu.

a. Azaleko asaldurak (lehortzea, hazkura, aknea, dekolorazioa, gorridura, hantura...)

b. Hanketako, oinetako, orkatiletako edota sabelaldeko hantura edo puztea.

c. Desorientazio-pasarteak edo oroimen-galerak.

d. Bihotzeko dardarak edo oso erritmo azeleratuko taupadak.

e. Espektorazioa, karkaxak edo flemak, edo itolarriaren sentsazioa etzaterakoan.

f. Begien edo azalaren kolorazio horixka.

g. Ez dut inongo sintomarik nabaritu.

1. taula. Ondorio kaltegarrien inguruko asteroko galdetegia. 


\section{Emaitzak}

24 pazienteri egin zitzaien elkarrizketa ikerketaren helburu eta ezaugarriak azaltzeko eta inklusioirizpideak betetzen zituzten baloratzeko (ikusi 2. taula). Paziente bakar batek zituen Osasun Karpetara sartzeko pasahitzak ikerketa hasi aurretik.

\begin{tabular}{|c|c|c|c|}
\hline Pazienteak & Kopurua (n) & Ehunekoa & $\begin{array}{c}\text { Batez besteko } \\
\text { adina }\end{array}$ \\
\hline Elkarrizketatutako pazienteak & 24 & $100 \%$ & 64 \\
\hline Inklusio-irizpideak betetzen ez zituztenak & $20 / 24$ & $83,3 \%$ & 66 \\
\hline $\begin{array}{l}\text { - Klabeak ez eskuratzeagatik (Interneten } \\
\text { erabiltzaile izanik) }\end{array}$ & $10 / 24$ & $41,7 \%$ & 63 \\
\hline - Internet ez erabiltzeagatik & $9 / 24$ & $37,5 \%$ & 70 \\
\hline - Hizkuntza-arazoengatik & $1 / 24$ & $4,1 \%$ & 58 \\
\hline Inklusio-irizpideak betetzen zituztenak & $4 / 24$ & $16,7 \%$ & 52 \\
\hline
\end{tabular}

2. taula. Inklusio-irizpideak eta pazienteen ezaugarriak.

Inklusio-irizpideak betetzen zituzten paziente guztiek erabaki zuten parte hartzea, adostasun informatua sinatuz. Horietako batek jarraipen-epea bukatu aurretik bertan behera utzi zuen ikerketa, haren egoera klinikoan emandako aldaketen ondorioz — datu analisietatik kanpo gelditu zen-.

Ikerketaren jarraipen-epea (12 aste) bukatu zuten hiru pazienteen artean, asteroko galdetegien betetze-tasa honako hau izan zen: 5 aldiz (atxikidura ertaina), 9 aldiz (atxikidura handia) eta 10 aldiz (atxikidura oso handia). Galdetegietan sarrien deskribatu ziren albo-efektuak, 3. taulan ikus daitezke:

\begin{tabular}{|c|c|c|c|c|c|c|}
\hline \multirow{2}{*}{ CTCAE eskala } & \multirow{2}{*}{$\begin{array}{l}\text { Sarrien adierazitako } \\
\text { ondorio kaltegarriak }\end{array}$} & \multicolumn{3}{|c|}{ Pazientea } & \multirow{2}{*}{$\begin{array}{c}\text { Jakinarazpenak } \\
\text { guztira }\end{array}$} & \multirow{2}{*}{$\begin{array}{c}\text { Galdetegien } \\
\text { ehunekoa }\end{array}$} \\
\hline & & 1 & 2 & 3 & & \\
\hline \multirow{5}{*}{ I gradua } & Nekea & 5 & 7 & 8 & 20 & $\% 83,3$ \\
\hline & Estomatitisa/disgeusia & 1 & 4 & 7 & 12 & $\% 50$ \\
\hline & Oin-eskuetako eritrodisestesia & 2 & 5 & 4 & 11 & $\% 45,8$ \\
\hline & Beherakoa & - & 2 & 3 & 5 & $\% 20,8$ \\
\hline & Apetitu galera & - & 1 & 3 & 4 & $\% 16,7$ \\
\hline \multirow{2}{*}{ II gradua } & Beherakoa & - & - & 1 & 1 & $\% 4,2$ \\
\hline & Oin-eskuetako eritrodisestesia & - & - & 1 & 1 & $\% 4,2$ \\
\hline III gradua & Bat ere ez & - & - & - & - & - \\
\hline IV gradua & Bat ere ez & - & - & - & - & - \\
\hline
\end{tabular}

3. Taula. Galdetegietan sarrien deskribatu ziren ondorio kaltegarriak, maiztasunaren eta CTCAE eskalaren arabera sailkatuta. 
Paziente guztiek erabili zuten ezarritako komunikazio-bide berria kontsultak egiteko. Denera 11 kontsulta egin zituzten (ikusi 4. taula). Pazienteen galderek eta jasotako galdetegien emaitzek, farmazialariek 15 mezu bidaltzea sustatu zuten.

\begin{tabular}{|c|c|c|c|c|c|}
\hline \multirow{2}{*}{ Pazienteen kontsulten gaia } & \multicolumn{3}{|c|}{ Pazientea } & \multirow{2}{*}{$\begin{array}{l}\text { Kopurua guztira } \\
\qquad(n=11)\end{array}$} & \multirow{2}{*}{$\begin{array}{c}\text { Kontsulten } \\
\text { ehunekoa }\end{array}$} \\
\hline & 1 & 2 & 3 & & \\
\hline Ondorio kaltegarrien maneiua & - & 1 & 4 & 5 & $\% 45,4$ \\
\hline Osasun Karpetarekin erlazionatutakoak & 1 & 1 & 2 & 4 & $\% 36,4$ \\
\hline Elkarrekintzak & - & 1 & - & 1 & $\% 9,1$ \\
\hline Administrazio-arazoak & 1 & - & - & 1 & $\% 9,1$ \\
\hline
\end{tabular}

4. taula. Osasun Karpetaren bitartez pazienteek egindako kontsulta kopurua.

Jarraian, pazienteen asebetetzea neurtzen zuen galdetegiaren emaitzak ikus daitezke 1 . irudian.

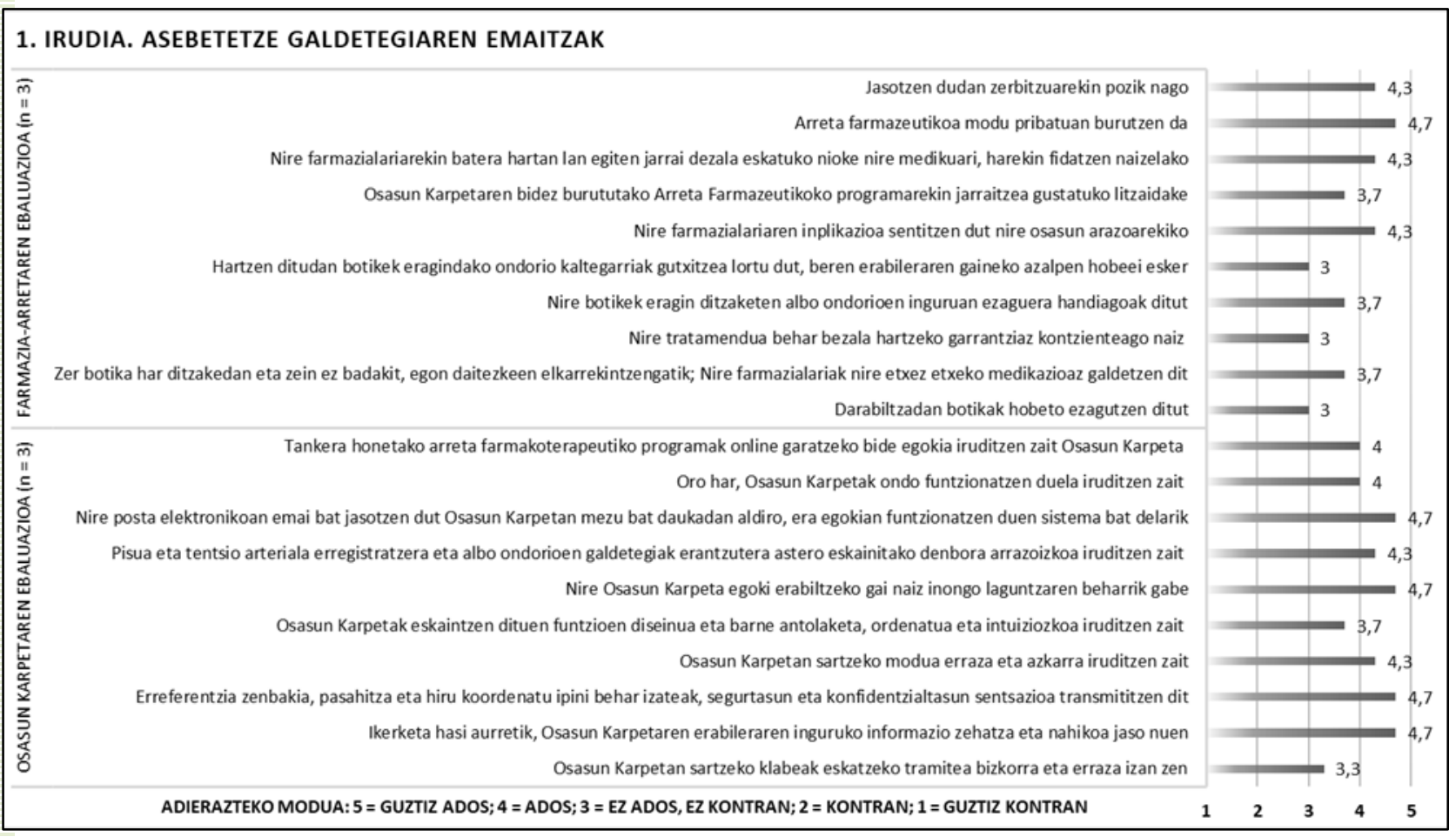

1. irudia. Asebetetze-galdetegiaren batez besteko emaitzak.

\section{Eztabaida eta ondorioak}

Osakidetzaren baliabide berriek eta, bereziki, Osasun Karpetaren garapenak sarearen bitartez zerbitzu-eredu berriak eskaintzeko ateak zabaldu zituen. Erreminta berri horretaz baliatuz, online eskainitako FA zerbitzuak gauzatzea bideragarria eta erabilgarria izango zelakoan abiatu genuen ikerketa hau. Lortutako emaitzak ondorio sendoak atera ahal izateko urriegiak izan ziren arren, itxuraz gure hipotesia indartzen zuten. 
Bideragarria zen, ikerketan parte hartu zuten paziente guztiek erantzun zituztelako ondorio kaltegarrien galdetegiak, eta gehiago edo gutxiago, denek erabili zutelako ezarritako komunikabide berria kontsultak egiteko. Haiek hautemandakoaren arabera, Osasun Karpeta baliabide aproposa zen konfidentziala eta segurua baitzen, eta erabiltzeko ez baitzen zaila.

Erabilgarria ere bazen, pazienteak jasotako zerbitzuarekin pozik gelditu zirelako, haien osasunarazoetan farmazialariaren inplikazioa sentituz. Galdetegietan adierazitakoaren arabera, FA telematikoari esker hobeto ezagutu zituzten gerta zitezkeen elkarrekintzak eta ondorio kaltegarriak.

Ikerketaren esplorazio-izaera kontuan hartuz, parte-hartze urria aztergai interesgarria izan zen ere. Arrazoiak aztertuz gero, pazienteen adin aurreratuak eta Osasun Karpetaren inguruko ezjakintasunak baldintzatu zutela dirudi. Izan ere, partaideen batez besteko adina (52 urte) inklusio-irizpideak betetzen ez zituztenena ( 66 urte) baino nabarmen txikiagoa zen; eta Interneten erabiltzaile ez zirenen kasuan, tartea handiagoa zen oraindik (70 urte). Horrek zera iradokitzen zuen: paziente gazteek IKT berriak erabiltzeko joera handiagoa zutela.

Bestalde, Osasun Karpetaren inguruko ezjakintasunari dagokionez, deigarria izan zen pazienteen \% 5ek ere ez zeukala sartzeko pasahitzik ikerketa hasi aurretik. Horrez gain, ikerketan parte hartzeko interesa erakutsi arren, paziente askok ez zituzten pasahitzak izapidetu. Gogoeta bezala, Osasun Karpeta gehiago ezagutzera eman beharko litzateke, eta pasahitzak eskuratzeko bideak erraztu.

Partaidetza ageriko muga izan zen arren, biztanleria Osasun Karpetarekin eta Internet eta IKT berriekin gehiago trebatu ahala, online eskainitako arreta-zerbitzuen interes handiagoa piztuko dela espero genezake, bideragarritasuna ere handituz.

Nazioartean, sintomak kudeatzeko garatutako sistema telematikoei erreparatzen badiegu, paziente onkologikoen karga sintomatikoa arintzeko tresna erabilgarria direla egiaztatu da, diagnostiko, etapa eta kimioterapia-erregimen desberdinekin (14). Nekea (15), mina eta depresioa (16) bezalako aldagai klinikoen gutxitzearekin erlazionatu dira sistema horiek, eta pazienteek sintomen maneiuen hobekuntzarekin eta osasun-profesionalekiko harremanen estutzearekin lotu dituzte (17).

Are gehiago; ebidentzia berrien arabera, minbiziaren tratamenduarekin lotutako sintomak online jakinaraztean, osasun-langileak e-mail automatikoen bidez ohartarazten dituzten sistemek zera erakutsi dute: Osasunarekin Erlazionatutako Bizi Kalitatea hobetzen dutela, larrialdietarako bisiten kopurua murriztuz, kimioterapia paliatiboaren iraupena luzatzea ahalbidetuz eta bizi-kalitateagatik doitutako biziraupena luzatuz (18).

Datu horiek guztiak kontuan hartuta, oso interesgarria izango litzateke online FA eredu berriak garatu eta hobetu ahal izateko beharrezkoak diren baliabideetan behar bezala inbertitzea. Gaixoen sintomatologia denbora errealean kudeatzen laguntzeko, gure iritziz, Osasun Karpetan erabakiorganigramak integratzea litzateke onena. Horrela, lehenetsitako muga klinikoak gainditzen dituzten ondorio kaltegarriek soilik (software-algoritmoen bidez balioztatuta) ohartarazi beharko lituzkete osasun-profesionalak. Eta gainontzeko sintomek pazienteen neurrira egokitutako autozaintzarako aholku automatikoak sortu beharko lituzkete, web sistema interaktibo bati esker.

Azken ondorio gisa, pazienteen ezagutza, erantzunkidetasuna eta ongizatea sustatzeko asmoz, Osasun Karpetaren bitartez eskainitako zerbitzu-eredu berrien alde egin behar dugu zalantzarik gabe, datozkigun garai berrietara egokituz, osasun-zerbitzuen erabiltzaileen gustuak aintzat hartuz eta efizientzia lehenetsiz. 


\section{Erreferentzia bibliografikoak}

1. Aisner J. Overview of the changing paradigm in cancer treatment: oral chemotherapy. AJHP. 2007 Mai 1;64(9 Suppl 5):S4-7.

2. ISMP List of High-Alert Medications in Community/Ambulatory Healthcare [Internet]. Institute for Safe Medication Practices; 2011 Urt 30 [Kontsulta: 2016-04-16]. Eskuragarri: https://forms.ismp.org/communityRx/tools/ambulatoryhighalert.asp

3. Escudero-Vilaplana V, Ribed A, Romero-Jimenez RM, Herranz-Alonso A, Sanjurjo-Saez M. Pharmacotherapy follow-up of key points in the safety of oral antineoplastic agents. Eur J Cancer Care. 2017 Mai 23;26(3).

4. Beck SL, Eaton LH, Echeverria C, Mooney KH. SymptomCare@Home: Developing an Integrated Symptom Monitoring and Management System for Outpatients Receiving Chemotherapy. Comput Infor Nurse. 2017 Urr;35(10):520-9.

5. McCorkle R, Ercolano E, Lazenby M, Schulman-Green D, Schilling LS, Lorig K, Wagner E. Selfmanagement: Enabling and empowering patients living with cancer as a chronic illness. CA Cancer J Clin. 2011 Urt-Ots;61(1):50-62.

6. Butow PN, Phillips F, Schweder J, White K, Underhill C, Goldstein D. Psychosocial well-being and supportive care needs of cancer patients living in urban and rural/regional areas: A systematic review. Support Care Cancer. 2012 Urt;20(1):1-22.

7. Howell DA, Smith AG, Roman E. Help-seeking behaviour in patients with lymphoma. Eur J Cancer Care. 2008 Uzt 8;17(4):394-403.

8. Vandyk AD, Harrison MB, Macartney G, Ross-White A, Stacey D. Emergency department visits for symptoms experienced by oncology patients: a systematic review. Support Care Cancer. 2012 Abu;20(8):1589-99.

9. Breen S, Ritchie D, Schofield P, Hsueh Y-S, Gough K, Santamaria N, Kamateros R, Maguire R, Kearney N, Aranda S. The Patient Remote Intervention and Symptom Management System (PRISMS) - a Telehealth- mediated intervention enabling real-time monitoring of chemotherapy side-effects in patients with haematological malignancies: study protocol for a randomised controlled trial. Trials. 2015 Urr 19;16:472.

10. Niznik JD, He H, Kane-Gill SL. Impact of clinical pharmacist services delivered via telemedicine in the outpatient or ambulatory care setting: A systematic review. Res Social Adm Pharm. 2018 Abu;14(8):707-717.

11. San-José B, Gil MA, Figuero MP. Atención farmacéutica y envío domiciliario de medicación a pacientes con leucemia mieloide crónica. Farm Hosp. 2015 Urt 1 ;39(1):13-22.

12. Real Decreto $1720 / 2007$, de 21 de diciembre, por el que se aprueba el Reglamento de desarrollo de la Ley Orgánica 15/1999, de 13 de diciembre, de protección de datos de carácter personal [Internet]. Boletín Oficial del Estado no 17, 19 de enero de 2008. [Kontsulta: 2016-04-16]. Eskuragarri: https://www.boe.es/buscar/doc.php?id=BOE-A-2008-979

13. Common Terminology Criteria for Adverse Events (CTCAE), Version 4.03 [Internet]. National Cancer Institute, National Institutes of Health, US Department of Health and Human Services; 2010 Eka 14. [Kontsulta: 2016-04-16]. Eskuragarri: https://ctep.cancer.gov/protocolDevelopment/electronic_applications/ctc.htm

14. Mooney KH, Beck SL, Wong B, Dunson W, Wujcik D, Whisenant M, Donaldson G. Automated home monitoring and management of patient-reported symptoms during chemotherapy: results of the symptom care at home RCT. Cancer Med. 2017 Mar;6(3):537-46.

15. Kearney N, McCann L, Norrie J, Taylor L, Gray P, McGee-Lennon M, Sage M, Miller M, Maguire R. Evaluation of a mobile phone-based, advanced symptom management system 
(ASyMS) in the management of chemotherapy-related toxicity. Support Care Cancer. 2009 Api;17(4):437-44.

16. Kroenke K, Theobald D, Wu J, Norton K, Morrison G, Carpenter J, Tu W. Effect of telecare management on pain and depression in patients with cancer: a randomized trial. JAMA. 2010 Uzt 14;304(2):163-71.

17. McCann L, Maguire R, Miller M, Kearney N. Patients' perceptions and experiences of using a mobile phone-based advanced symptom management system (ASyMS) to monitor and manage chemotherapy related toxicity. European J Cancer Care. 2009 Mar;18(2):156-64.

18. Basch E, Deal AM, Kris MG, Scher HI, Hudis CA, Sabbatini P, Rogak L, Bennett AV, Dueck AC, Atkinson TM, Chou JF, Dulko D, Sit L, Barz A, Novotny P, Fruscione M, Sloan JA, Schrag D. Symptom Monitoring With Patient-Reported Outcomes During Routine Cancer Treatment: A Randomized Controlled Trial. J Clin Oncol. 2016 Ots 20;34(6):557-65. 